\title{
NEW SPECIES OF TRETOSPORA (FUNGI IMPERFECTI: HYPHOMYCETES) FROM KERALA, INDIA
}

\author{
V.B. Hosagoudar, P.A. Jose and A.G. Pandurangan \\ Microbiology Division, Tropical Botanic Garden and Research Institute, Palode, Thiruvananthapuram, Kerala 695562, India
}

\begin{abstract}
Tretospora ochreinaucleae is a new species described and illustrated on an endemic plant Ochreinauclea missionis from Kerala, India.

Keywords

Hyphomycetes, new description, Tretospora ochreinaucleae sp. nov., Kerala, India
\end{abstract}

\section{Introduction}

During the study of reproductive biology of Ochreinauclea missionis, an endemic plant of the Western Ghats of Peninsular India (Ahmedullah \& Nair, 1986; Ahmedullah, 1990; Jose et al., 2000), a severe fungal infection was noticed on the leaves. The fungus persisted round the year in its anamorph state and also produced perithecia without asci.

\section{Tretospora ochreinaucleae sp. nov.}

(Fig.-1)

\section{Material examined}

Holotype: 10.x.2000, Tropical Botanic Garden and Research Institute Campus, Palode, Thiruvananthapuram, Kerala, India, coll. Jose, on leaves of Ochreinauclea missionis (Wallich ex G. Don) Ridsd. (Rubiaceae), HCIO 43978.

Isotype: TBGT 408

\section{Etymology}

Named after the host genus Ochreinaucleea

\section{Diagnostic features}

Coloniae foliicolae, amphigenae, plerumque hypophyllae, nigrae, densae, patentiae, ad $2 \mathrm{~mm}$ diam., confluentes. Hyphae pallide brunneae, subrectae vel leniter sinuosae, irregulariter ramosae, ad angulum acutum vel latum

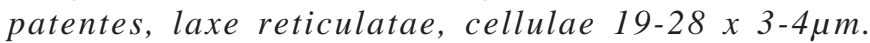
Appressoria alternata, unilateralia, raro opposita, sessilia, globosa, fortiter brunnea, sublobata vel lentiter lobata, 7 $9 \times 6-7 \mu m$. Conidiophora ex hyphis lateraliter oriunda, numerosa, macronemata, mononemata, unicellularia, plerumque recta, raro leniter curvata et flexuosa, ad basim

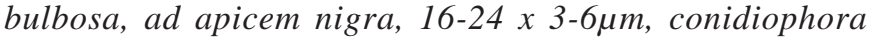
idem est ac cellula conidiogena. Cellulae conidiogenae enteroblasticae, monotreticae, ad apicem nigrae. Conidia solitaria, ex poris terminalibus oriunda, sicca, recta vel curvula, simplices, obclavata, rostrata, pallide brunnea, glabra, 1-5- septata, raro constricta, truncata ad basim, hilum nigrum, ad apicem late rotundata, 32-72 x 3-5 $\mu \mathrm{m}$.

Colonies foliicolous, amphigenous, mostly hypophyllous, black, dense, spreading, up to $2 \mathrm{~mm}$ in diameter, confluent. Hyphae pale brown, substraight to slightly sinuous, branching irregular at acute to wide angles, loosely reticulate, cells 19-28 x 3-4 $\mu \mathrm{m}$. Appressoria alternate, unilateral, rarely opposite, sessile, globose, deep brown, sublobate to deeply lobate, 7-9 x 6-7 $\mu \mathrm{m}$. Conidiophores produced laterally from the hyphae, numerous, macronematous, mononematous, unicellular, reduced to conidiogenous cells, mostly straight, rarely slightly curved to flexuous, bulbous at the base, black at the tip, 16-24 x 3-6 $\mu \mathrm{m}$. Conidiogenous cells enteroblastic, monotretic, apical rim black. Conidia solitary, produced from the apical pore, dry, straight to curved, simple, obclavate, rostrate, pale brown, smooth, 1-5- septate, rarely constricted at the septa, truncate at the base, hilum dark, broadly rounded at the apex, $32-72 \times 3-5 \mu \mathrm{m}$.

Numerous collections of this fungus revealed only conidia and the initials of perithecia. Sivanesan (1981) gave an account of twelve species of the genus Balladynopsis and categorised them into four groups. Of them, the species 
with entire appressoria have Tretospora anamorphs. Hence, the present species differs from them in having sublobate to lobate appressoria. Tretospora himalayana Chaudhary \& S.K. Singh and T. shoreae M.K. Khan and Kamal are known on hosts of Thymelaeaceae and Dipterocarpaceae (Chaudhary \& Singh, 1996; Khan et al., 1993). Tretospora indica Narayan \& Kamal and T. theitei Hosag. et al. are known on the members of the family Rubiaceae (Narayan \& Kamal, 1986; Hosagoudar et al., 1998) but the present species differs from both in having sublobate to lobate appressoria.

\section{Acknowledgements}

Thanks are due to Dr. G.M. Nair, Director, and Dr. T.K. Abraham, Deputy Director, TBGRI, Palode for the facilities. Dr. U. Braun is gratefully acknowledged for the review of the manuscript.

\section{References}

Ahmedullah, M. (1990). In: Nayar, M.P. and A.R.K. Sastri (Editors). Red Data Book of Indian Plants 3: 222-223. Botanical
Survey of India, Culcutta.

Ahmedullah, M. and M.P. Nayar (1986). Endemic Plants of the Indian Region. Vol. 1. Peninsular India, p. 161. Botanical Survey of India, Culcutta.

Chaudhary, R.K. and S.K. Singh (1996). Notes on hyphomycetes- LXXI. New species of Stenella, Stenellopsis and Tretospora from Nepal. Mycotaxon 57: 201-209.

Hosagoudar, V.B., T.K. Abraham, N. Ahamad and A.K. Sarbhoy (1998). Tretospora thetei sp. nov. from Maharashtra. Indian Phytopathology 51: 387-388.

Jose, P.A., A.G. Pandurangan and J. Thomas (2000). Ecology and conservation of Ochreinauclea missionis: A case study for the rare and endemic trees of Western Ghats, pp. 576-580. Twelfth Kerala Science Congress.

Khan, M., K. Kamal and G. Morgan-Jones (1993). Notes on hyphomycetes-LXIII. Noval species of Fuligomyces and Tretospora from India, with comments on the genera. Mycotaxon 49: 477-485.

Narayan, P. and K. Kamal (1986). New foliicolous hyphomycetes from India. Canadian Journal of Botany 64: 201-207.

Sivanesan, A. (1981). Balladynopsis, Balladynocallia and Alina. Mycological Paper 146: 1-38 + viii plates.

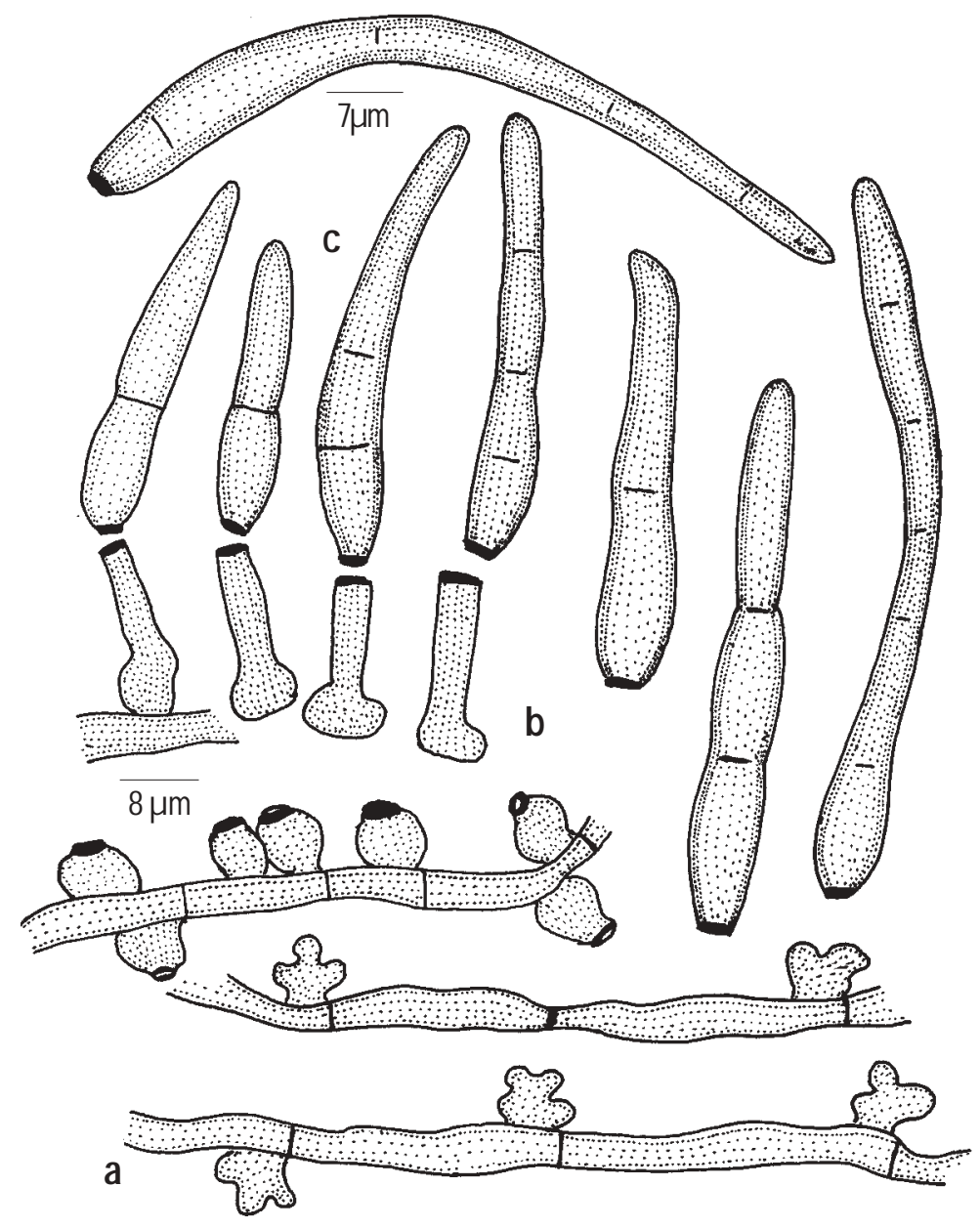

Figure 1. Tretospora ochreinaucleae sp. nov. a - Appressoriate mycelium; $\boldsymbol{b}$ - conidiophores; $\boldsymbol{c}$ - conidia 